\title{
THE PERMANENT CAMPAIGN IN SOCIAL MEDIA: A CASE STUDY OF POLAND
}

\author{
Dorota Domalewska ${ }^{1}$
}

\begin{abstract}
New media technologies provide new venues for political communication enabling politicians to wage a permanent campaign. Participatory platforms have paved the way for new forms of political communication during non-election period when those seeking or holding office can increase media coverage, create their public image and foster deeper relationships with the public. The purpose of the paper is to contribute to the discussion on permanent campaign; specifically, the study focuses on presenting the method of embracing new media technologies (in particular Twitter) by politicians' during a non-election period in Poland. The analysis aims to investigate online activity, the design of Twitter profiles and the implementation of campaign-like techniques by the politicians. The findings shed light on the Polish MPs' application of participatory platforms as a tool of strategic communication used to increase media visibility, and share messages across in a one-way communication.
\end{abstract}

Keywords: social media, Twitter, permanent campaign, political communication, political marketing strategies

\section{Introduction}

Social media have led to a major shift in the way political campaigns are run and won. Social networking sites provide new venues for campaigning, debates and activism. Not only do new actors, such as political bloggers and activists, take an active role in the public discourse but also politicians post, share and comment current events as they are unfolding. Social media have paved the way for new forms of political participation that never before existed [1] where individual politicians can increase their media exposure [15], ensure contact with their electorate [19] and boost popularity during both election and non-election periods thus allowing for permanent campaign to take place.

The present paper investigates online political communication of Polish MPs during non-election period. In particular, active Twitter accounts of all members of the lower house of the Polish parliament $(\mathrm{N}=460)$ were analyzed in order to answer the following research questions: (1) How do MPs build their Twitter profile?; (2) Which campaign-like techniques do MPs implement on Twitter? In order to answer the research questions, content analysis of MPs' Twitter accounts has been performed. The aim of the analysis was to investigate the politicians' use of new media technologies. The study focused on design, online presence, and political marketing strategies employed by politicians.

\footnotetext{
${ }^{1}$ War Studies University, Faculty of National Defence, Warsaw, Poland, d.domalewska@akademia.mil.pl
} 


\section{Permanent campaign in Poland}

The contemporary politics has taken the form of permanent campaign where media coverage and public popularity have become the unswerving focus of politicians thus turning governing into campaigning [4]. Thus, permanent campaign involves "adopting the campaigning style of governing to retain or even increase [politicians'] popularity, motivated by the institutional, political, and technological evolutions including mainly the decline of parties, the rise of television, and the advent of new political technologies" [14].

When the distinction between campaigning for national office and holding office becomes vague, several features increase in importance: strategic calculation involved in public image creation, building public support [25], growing interest in opinion polls [21, 22], policy contestation, extensive media exposure [27], focus on fund-raising [7] and media preoccupation with popularity of individual politicians. Opinion polling and resorting to professional campaign consultants have begun to shape political strategy during non-election periods because it is one of the most reliable tools that reveal citizens' opinion, interests, attitudes, preferences, approvals and prejudice the knowledge of which helps to gain electoral success. President Bill Clinton used market research and public relations memos to maintain public support [10], Barack Obama turned to pollsters for advice on developing more persuasive strategies [22] whereas Tony Blair employed market research analysts from the US who advised him on communication strategies and to keep track of popularity ratings [21].

At the permanent campaign age, maintaining popularity has become a key focus of major politicians holding office. Media coverage is one of the elements that can help to win popularity. Politicians have at their disposal several tools they willingly use to step into the spotlight; for example, they might share personal stories, which turns politicians into celebrities. Antagonism and multi-dimensional conflict are other ways that increase media visibility. Thus, constant image making as well as a struggle for visibility and unswerving popularity have become increasingly important in today's digital age.

\section{Social media - a permanent campaign instrument}

Politicians eagerly use Internet-based tools (such as websites, e-mail, forums) and social media to get their message across. In particular, social media have become a popular instrument of creating positive public image and boosting popularity of individual politicians not only due to low cost and expected broad reach [17] but also owning to innumerable benefits: ease of sharing information, mobilizing citizens, and fund-raising [8]. Politicians can easily bypass media gatekeepers and refer directly to citizens, social media users. Traditional mass media tend to favour major political actors and adhere to a predetermined political or ideological line of the publishing house [15] whereas posting messages or tweeting provides politicians with an additional option to access and shape information. The internet increases the visibility of small and fringe parties, thus becoming a free marketing tool [24], which political actors make use of to step into the spotlight or presenting unfavourable events in a favourable light. Politicians select information to be posted, take autonomous decisions on creating their profile, and build self-controlled authenticity [18]. Thus, social media users get up-to-date news stimulating their attention, which is both an ingredient of marketing communication and an element of the permanent campaign. Social media users become spectators of the political drama evolving in front of their eyes, which on the one hand keeps them glued to their mobile device and on the other hand could lead to information chaos [20]. 
In Poland, the Internet became the arena of political campaign for the first time in 1997 during the parliamentary campaign. At that time first websites and chats of the political parties taking part in the campaign were developed [3] and campaign ads were shared in the new media (mainly YouTube) [2]. Websites make convenient platforms for sharing content (e.g. election programmes, politicians' profiles, current news, etc.) delivered through attractive design that aims at creating a credible and stable image [16]. Websites are interactive in nature (e.g. discussion forum, chat), which is engaging for citizens and helps to form a virtual community. However, at present politicians tend to turn their websites into a notice board: they only share and update information but fail to provide any feedback [6]. A study carried out by Ward et al. [26]shows that less than a third of the websites run by political parties in the UK enables citizens to share their opinions in online forums, chats, or provide another form of interaction. Similarly, in Poland political parties fail to make use of the websites' possibility to form a virtual community [16]. Even if a website offers a discussion forum, it usually does not perform its primary function, namely two-way communication with citizens and political discussion.

Social networking platforms have changed the nature of political communication. They have become a popular political marketing tool; due to the potential symmetrical and real time nature of communication social media facilitate building relations and increasing engagement. However, oneway communication prevails when a great number of politicians enthusiastically post messages and tweet, but rarely comment them [26], which resembles traditional though independent media. Despite limited interaction between political actors and social media users, it is social media, not self-hosted websites, that have become platforms where campaign-like activities are carried out. Social networking sites enable politicians to select the content and time they update their status or tweet. Moreover, every tweet or post can include a hyperlink to a website. On average every fourth tweet in election campaign in Australia in 2010 [5] and in Belgium in 2012 [9] redirected users to a website of mainstream media or another social platform (Twitter, YouTube, blogs, Instagram, Facebook and other). Most frequently the hyperlinks were shared alongside a photograph, which proves the advantage of visual over graphic content. Numerous studies have proved that online presence has had a positive impact election results in Brazil [12], in Turkey [23], in Australia [11], and the US [8]. Few studies point at the limited effect of online campaigning; for example, Hansen and Kosiara-Pedersen [13] found that using online tools correlates with election results of sameparty candidates rather than inter-party competition.

Politicians use several permanent campaign strategies during non-election periods. First, building trust is a fundamental marketing strategy that facilitates forming a relationship with a customer or electorate. Politicians develop trust when they are transparent, react to feedback, explain adequately so that all ambiguities and understatements are resolved. Politicians should convey an impression of a credible and pleasant personality. Furthermore, trust can be developed through direct contact. New media users differs significantly from the mass consumption consumers in that they want to be treated individually. To meet this demand, marketing companies make use of a variety of online tools that scan new media users' online behavior in order to offer them personalized content. Finally, it is vital to establish a regular contact with users. Politicians should react to users' messages and challenge them rather than merely post media statements.

\section{Research methodology}

Taking into consideration the impact social networking platforms have on political communication, the present study focuses on MPs' use of social media, in particular Twitter, to communicate with the public during non-election periods. The following research questions were addressed in the 
study: (1) How do MPs build their Twitter profile? (2) Which campaign-like techniques do MPs implement on Twitter?

The present study draws on data collected from all members of the lower house of the Polish parliament who had an active Twitter account at the time of data collection, i.e. August-September 2017. Out of 460 MPs holding office at a lower house, the Sejm, 238 have active Twitter profiles. The analysis was carried out in several steps. First, Twitter analytics tools were used to evaluate Twitter data (such as a number of tweets, retweets, followers). Next, each Twitter account was analyzed using Content Analysis technique, which helps to gain systematic, objective and quantitative analysis of data. Observations were recorded in a schedule with predetermined categories which focused on examining in detail the design, online presence, and political marketing strategies employed by the politicians.

\section{Results and discussion}

Design of a Twitter profile is the first factor that projects the user's identity; that is why, both politicians and professional campaign consultants expend considerable effort to organize the profile page so that it presented the politician properly, generated more traffic and increased visibility. The effective use of color, profile and header picture, as well as aesthetic appeal are factors that create the first impression whereas the user bio, infinitely scrollable timeline of the user's tweets, videos, photos, and shared tweets build the user's personal brand.

The analysis of the MPs' profile picture shows that most politicians (97\%) select a formal head and shoulders portrait photograph in smart outfit, which creates an impression of a competent and compelling professional. Not many politicians display a photograph of themselves with their spouse or other citizens; few politicians upload a photograph of an object (emblem, horse or an abstract image). The selection of the header photograph is done in a more varied way, which is presented in Figure 1.

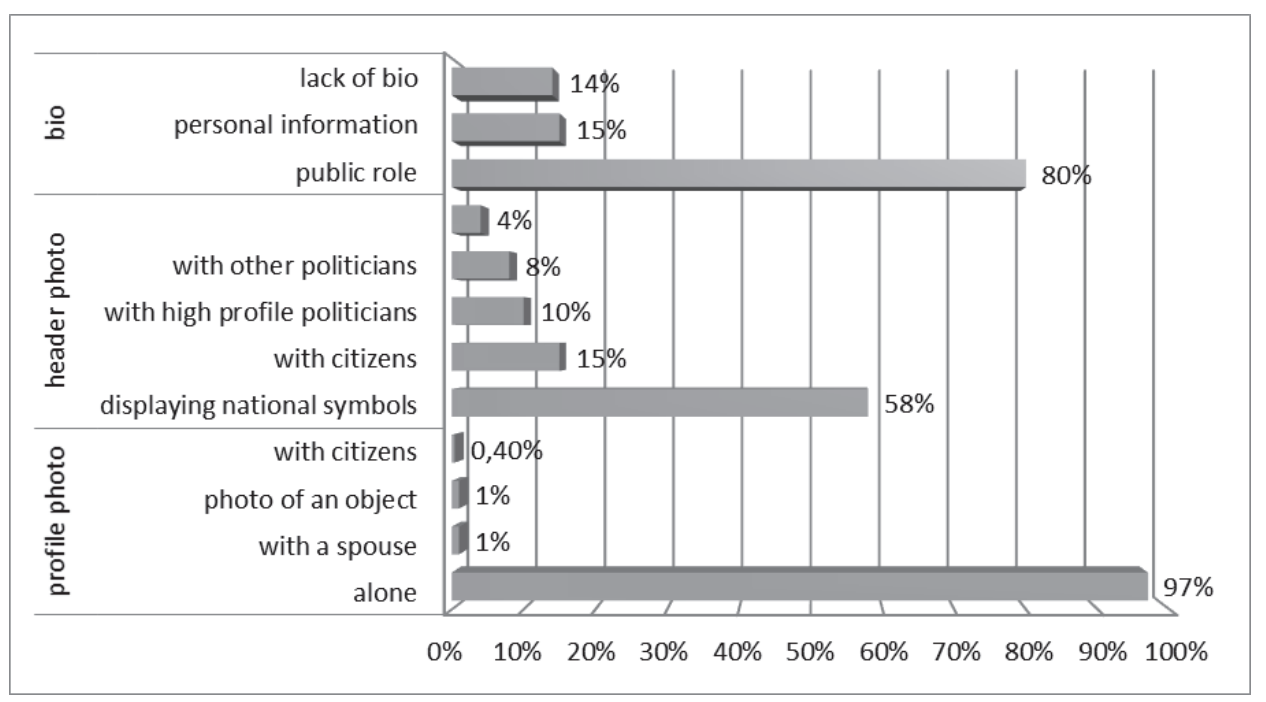

Figure 1: Strategies used to build a Twitter profile 
Most MPs display a symbol in their header photo: national symbols, party identification (including a number of key words or hashtags, i.e. social or political priorities the MP stands for) or a landscape (most frequently a city landscape). Others set a header photo presenting other politicians or citizens. A great number of politicians include a short bio that mostly discusses their public roles. Few politicians opt for sharing personal information about their family, education or hobby. Thus, Twitter accounts of the MPs are mainly used as an alternative method of presentation the politician profile in the formal context.

The three elements of a Twitter profile: profile photo, header photo and bio give a hint of the user's identity. Clearly, the Polish MPs intend to create a professional image: through the selection of photographs they project themselves as competent politicians who cooperate with other politicians and perform their constituency roles. Needless to say, the content is carefully selected to display their professionalism (photographs with citizens and other politicians, a bio showcasing their duties), values (header photograph including national or party symbols as well as slogans that emphasize their priorities), and approachability (family photographs, a bio revealing their hobby).

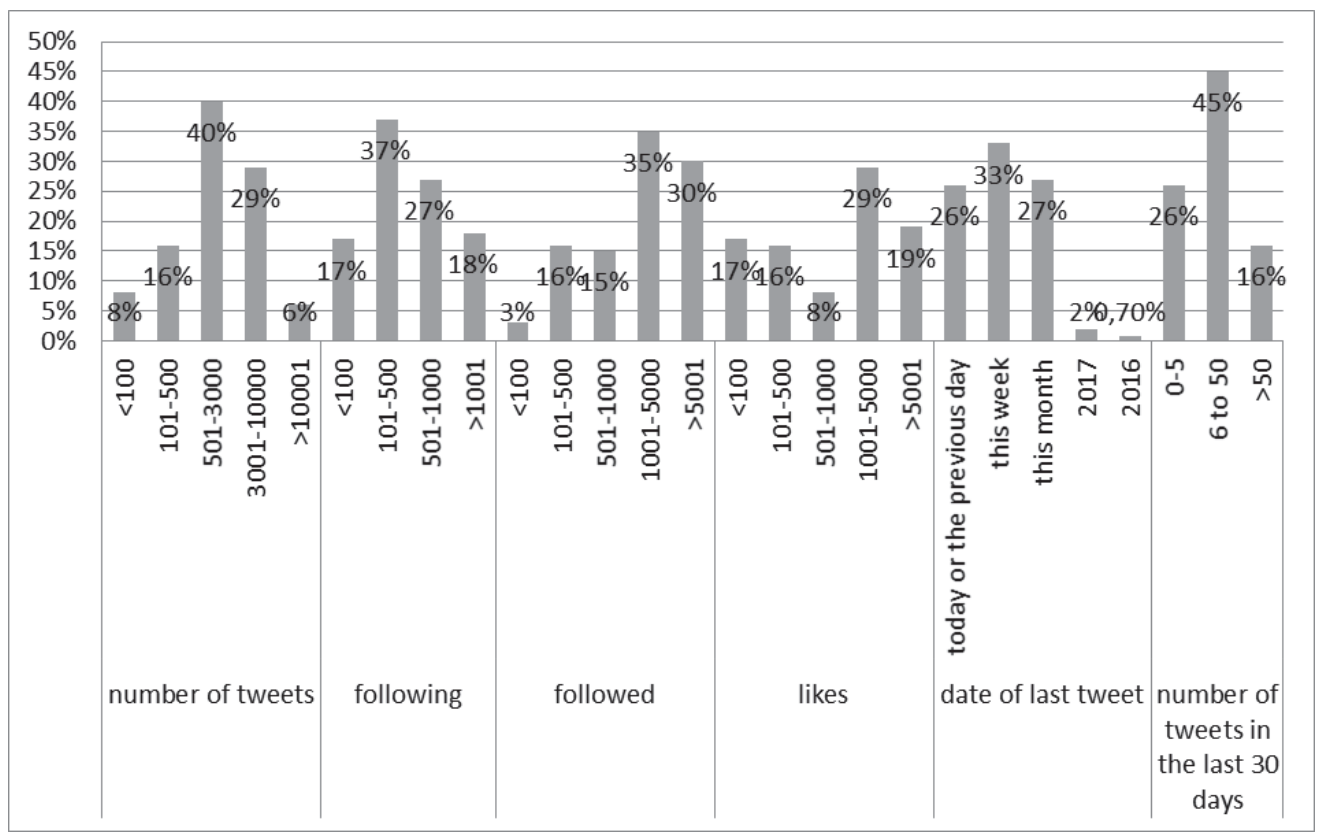

Figure 2: The MPs' activity on Twitter

The findings displayed in Figure 2 clearly show that the MPs are rather observed that observing other profiles. Undoubtedly, high-profile politicians attract the greatest number of observers. This finding proves that, on the one hand, Twitter is an instrument used by politicians to get their message across to both the electorate and the media. Thus, they use Twitter as a word-of-mouth instrument, but the limited number of accounts they follow proves that they do not listen to other messages very attentively. On the other hand, the MPs massively share tweets posted by other politicians or the media rather than tweet original content, which is both easier and less facethreatening than, but still serves the main purpose: stepping into the spotlight. Posting a content tweet requires in-depth analysis and responsibility (all tweets can be potentially widely 
commented). At the same time, it ensures online visibility, which is of utmost importance. Thus, in both cases, Twitter is used as a tool that increases media coverage. Furthermore, the tweets that are most frequently shared are repetitive and predictable: the MPs publicize media coverage of important events, inform about their presence in traditional media, present results of their work, and reproach their political opponents.

Finally, a great number of politicians $(21 \%)$ present the results of polls whose aim is to prove popularity of individual politicians, parties, or actions (members of the ruling party present research results to prove effectiveness of their reforms whereas members of the opposition publicize statistics to prove the contrary). Thus, opinion polling has been widely used during non-election periods in order both to ensure the politicians' public support and to bring the opposition into disrepute.

\section{Conclusions}

Politicians incorporate social networking platforms into their strategic communication with the public due to their low cost and expected broad reach. Social media have become an invaluable tool that helps to fulfil several objectives: reaching and mobilizing general public, increasing media visibility, ensuring online presence, building popularity, and creating positive public image. The research proves that social media have become an integral part of governing that facilitates political communication on the national level. First, each MP's profile is created paying close attention to detail: the effective use of colour, profile and header photograph, bio, and aesthetic appeal. The politicians in Poland are presented as competent and persuasive professionals who cooperate with other politicians, perform their constituency roles, cherish a set of values and are approachable. Not many MPs upload photographs of their family nor share private information. A common strategy is to post a symbol in their header photo, most frequently national symbols, party identification (including a number of key words or hashtags, i.e. social or political priorities the MP stands for) or a landscape.

Furthermore, the Polish politicians holding parliamentary power tend to rely on sharing tweets rather than updating their profiles with original tweets and are followed rather than following other profiles. This finding proves that the MPs use participatory platforms to increase media visibility and share their message across in a one-way communication. Finally, they frequently display the results of opinion polls, mainly with the aim to prove their popularity or to bring the opposition into disrepute.

\section{References}

[1] ANDUiZA, E., CANTIJOCH, M. \& GAllEGO, A., Political Participation and the Internet -a Field Essay. Information, Communication \& Society, Vol 12, No 6, pp. 860 - 878, 2009.

[2] ANNUSEWICZ, O., Celebrytyzacja Polityczna, in: Studia Politologiczne, 20, 268-278, 2011.

[3] BISKUP, B., Komunikowanie Polityczne w Tradycyjnych i Internetowych Serwisach Informacyjnych - Analiza Przejawów Kultury Politycznej przed Wyborami Prezydenckimi w Polsce w 2010 Roku, in: Studia Politologiczne, 26, 109-131, 2011.

[4] BLUMENTHAL, S. L., The Permanent Campaign: Inside the World of Elite Political Operatives. Boston, Beacon Press 1980. 
[5] BRUNS, A., and BURGESS, J., \#ausvotes: How Twitter Covered the 2010 Australian Federal Election, in: Communication, Politics and Culture, 44(2), 37, 2011.

[6] CASTELLS, M., The Internet Galaxy: Reflections on the Internet, Business and Society, New York, 2002.

[7] CORRADO, A., Running Backward: The Congressional Money Chase, in: N. Ornstein and T. Mann (eds), The Permanent Campaign and its Future, Washington DC: American Enterprise Institute and the Brookings Institute, pp. 75-107, 2000.

[8] DAVIS, R., BAUMGARTNER, J. C., FRANCIA, P. L., and MORRIS, J. S., The Internet in US Election Campaigns, in: Routledge Handbook of Internet Politics, 25-39, 2009.

[9] D'HEER, E., and VERDEGEM, P., An Intermedia Understanding of the Networked Twitter Ecology, in: B. Pătruţ, M. Pătruţ (eds) Social Media in Politics, Springer, Cham, 81-96, 2014.

[10] EDWARDS, G., Campaigning is not Governing: Bill Clinton's Rhetorical Presidency, in: C. Campbell and B. Rockman (eds) The Clinton Legacy, London, 33-47, 1999.

[11] GIBSON, R. K. and MCALLISTER, I., Does Cyber-campaigning Win Votes? Online Communication in the 2004 Australian Election, in: Journal of Elections, Public Opinion and Parties, 16(3), 243-263, 2006.

[12] GILMORE, J., Ditching the Pack: Digital Media in the 2010 Brazilian Congressional Campaigns, in: New Media and Society, 14(4), 617-633, 2012.

[13] HANSEN, K. M., and KOSIARA-PEDERSEN, K., Cyber-campaigning in Denmark: Application and Effects of Candidate Campaigning, in: Journal of Information Technology and Politics, 11(2), 206-219, 2014.

[14] HECLO, H., Campaigning and Governing: A Conspectus, in: N. Ornstein and T. Mann (eds) The Permanent Campaign and its Future, Washington, 1-37, 2000.

[15] JEZIŃSKI, M., Po co Politykom Nowe Media? O Politycznym Istnieniu w Wirtualnej Przestrzeni, in: Nowe Media. Czasopismo Naukowe, 2, 11-30, 2011.

[16] KANCIK, E., Budowanie Wizerunku - Strony Internetowe Polskich Partii Politycznych, in: M. Wincławska (ed.) Partie Polityczne w Początkach XXI Wieku. Problemy Rozwoju, Organizacji i Funkcjonowania, Toruń, 2013.

[17] LARSSON, A. O., Online, all the Time? A Quantitative Assessment of the Permanent Campaign on Facebook, in: New Media and Society, 18(2), 274-292, 2016.

[18] LESZCZUK-FIEDZIUKIEWICZ, A., Internet jako Narzędzie Kreowania Wizerunku Polityka, in: Nowe Media. Czasopismo Naukowe, 2, 31-54, 2011.

[19] NOWINA-KONOPKA, M., Rola Internetu w Rozwoju Demokracji w Polsce, Kraków Nowy Sącz, 2008. 
[20] PIONTEK, D., Komunikowanie Polityczne i Kultura Popularna. Tabloidyzacja Informacji o Polityce, Poznań, 2011.

[21] SCAMMEL, M., The Media and Media Management, in: A. Seldon (ed.) The Blair Effect, London, 509-533, 2001.

[22] SMITH, J. F., Obama Adopting Permanent Campaign Strategy, Boston, 2009.

[23] SOBACI, M. Z., ERYIGIT, K. Y., and HATIPOGLU, I., The Net Effect of Social Media on Election Results: The Case of Twitter in 2014 Turkish Local Elections, in: Social Media and Local Governments, 265-279, 2009.

[24] STRANDBERG, K., Online Campaigning: An Opening for the Outsiders? An Analysis of Finnish Parliamentary Candidates' Websites in the 2003 Election Campaign, in: New Media and Society, 11(5), 835-854, 2009.

[25] VERGEER, M. and HERMANS, L., Campaigning on Twitter: Microblogging and Online Social Networking as Campaign Tools in the 2010 General Elections in the Netherlands, in: Journal of Computer-Mediated Communication, 2013.

[26] WARD, S. J., GIBSON, R. K., LUSOLI, W., Online Participation and Mobilization in Britain: Hype, Hope and Reality, in: Parliament Affairs, 56(4), 652-668, 2003.

[27] WEINER, M. D., The Party's Still on: American Political Parties from 1950 to 2005, in: R. A. Harris, D. J. Tichenor (eds) A History of the U.S. Political System, Santa Barbara, 22-40, 2010 .

[28] ZARĘBA, A., Permanent Campaign in Poland - Causes, Elements, Importance, in: Political Preferences 13, 97-113, 2016. 